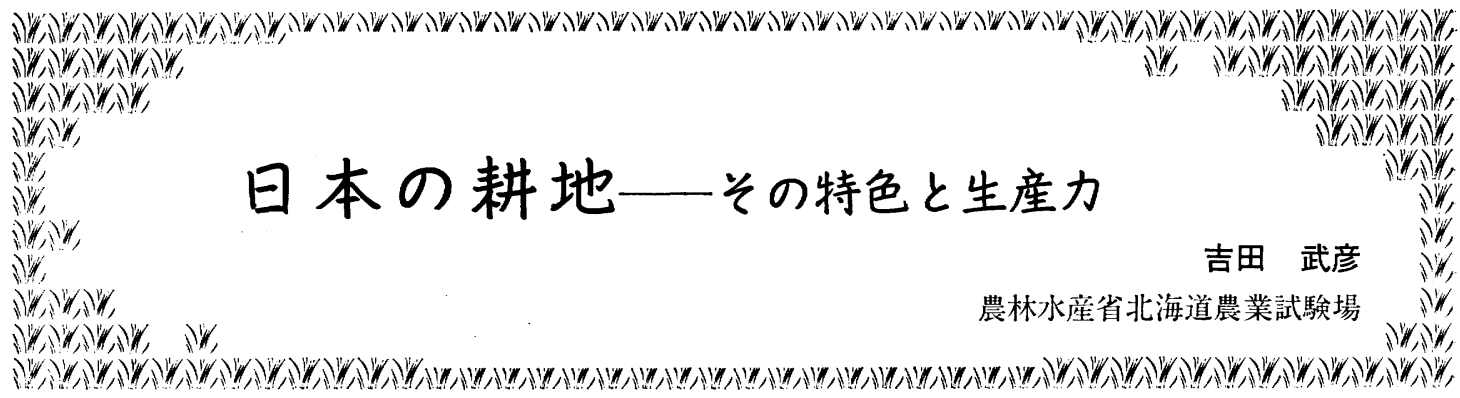

\section{1. 遅い耕地化の始まり}

私たちが住む日本列島での農業の始まりは，いかにも 唐突という印象を受ける．日本列島に人が住みだしたの は, 数万年以上をさかの涪るとされ，原人の居住の可能 性もあるらしいが，少なくとも約 1 万年以前には，私た ち現在の日本人と直接血のつながりのある人たちが，縄 文時代の幕を開いていた．縄文時代人は，世界で最も古 い時期から土器を作り始め，奇怪ではあるけれどる芸術 性の豊かな土器文化を発達させていたにもかかわらず， 約 8,000 年の縄文時代のほとんどをつうじて，農耕を知 らなかった．縄文時代人の生活は，狩孜・漁労・採集で 支えられ，基本的な食料は堅果つまりドングリ類であっ たとされている.

ところが，縄文晚期の終末に近い紀元前 4 世紀ごろ， 突如として北九州に水田稲作が現われる.この稲作の渡 来は，縄文文化に終止符を打って，弥生文化を発生させ る原動力になり，稲作農耕は紀元 3 世紀には本州の北端 にまで達した． 8,000 年にわたる無農耕の縄文時代のの ち，稲作農耕は弥生時代の幕を開きつつ，わずか 600 年 あまりで，北海道を除く日本列島全体を席巻したわけで ある。

狩猟・漁労・採集から農耕への変化は，日本列島の人 口扶養力に飛躍をるたらした．図 1-A は，小山(1)が時代 別遺跡数をもとにして推定した縄文時代の人口分布であ るが，最大人口に達した縄文中期でも，北海道以外の全 国人口注約 26 万人にすぎず，しかも後期，晚期になる につれて，逆に著しい減少をみるのである，一方，わが 国が明瞭に農耕時代に入った弥生後期には，人口は，図 1-B のように縄文晚期の約 8 倍增という劇的な変化を示 し，また，農業の基礎が 固まった 8 世紀の 奈良時代に は，人口がさらに約 9 倍増する．稲作を中心とした農耕 の始まりが，わが国の人口扶養力に与えたインパクトが
ぞんなに大きなものだったか，明らかであろう。

このように，日本列島の人口扶養力を爆発的に高めた 農耕の幕明けには，いくつかの謎がある．第一に，稲作 の渡来に始まる農耕の開始が，周辺諸国に比べてひどく 遅れたこと, 第二に, 稲作に伴う耕地すなわら水田が, いきなり区画され，水路も整備されるといった完成され た形が現われること，第三に，気候条件のかなりな相違 にもかかわらず，異常ともい方る速さで本州北端まで伝 わったことなどである，第一の点に関していえば，東南 アジアに打ける稲作の 起源は紀元前 6000 年ごろとさ れ，日本への稲作渡来の出発点といわれる中国の揚子江 下流地方でも，紀元前 1500 年にはすでに稲作が広く行 なわれていた。それから数えても，日本列島に稲作農耕 が伝わるまでに 1,000 年以上のずれがある. 縄文時代に は漁労が広く行なわれ，立派な丸木舟が存在していた。 一方，中国の殷周時代に栄えた揚子江下流文化は，外洋 航行の可能な船船を持っていたようである.したがって， 稲作文化は, 縄文時代にも何回か日本列島に到達したで あろらし，縄文人もそれに接触するチャンスはあったは～ ずである。

それにもかかわらず，稲作農耕は，揚子江下流域に遅 れること千数百年にして，ようやく北九州に入りえたの だし，いきなり高度に完成された水田を伴ってわが国に 現われるのである．こうしてみると，縄文時代の日本に は，何か稲作農耕を拒否する要因があったのではないだ ろらかと考えたくなる。

狩猟採集民族が，たと兄多くのチャンスがあったとし ても，そう簡単に農耕を受け入れるものでないことは， 民族学研究の定説であるし，日本列島での農耕開始がか くも遅れて始まった理由は，狩編採集を基礎にした䋥文 文化がかくも長く続いた理由とともに，容易に結論の出 せる問題ではない，しかし，私はその理由の一つとして 日本の自然生産力の高さがあげられるのではないかと考 

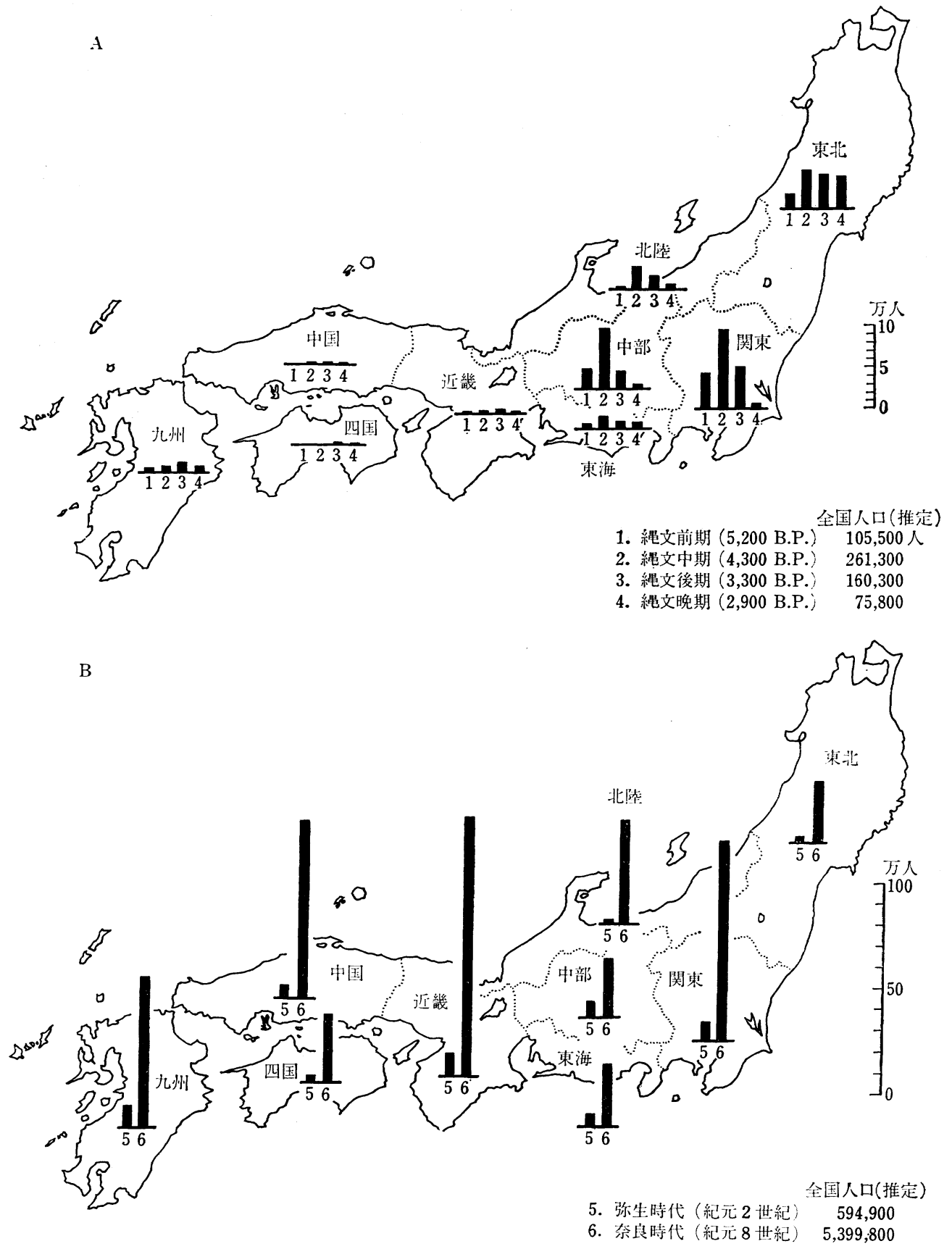

図 1 緡文時代 $(\mathrm{A})$ および弥生・奈良時代における人口分布 $(\mathrm{B})$ (小山息により作図)

える.

気候带からみて，日本の自然生態系は森林であると して，北海道と南西諸島を除いて，東日本から東北日本 汇かけての落葉広葉樹林と西日本の照葉樹林の二つが代 表的な生態系をなしている．現在でも森林はわが国土の 約 7 割を占めているが，農耕開始前には，おちとら 9 割
以上がうっそうたる森林で覆われていたろら，といわれ る.ところで，表 1 は Whittaker(2) による地球上の各生 態系の平均的な一次生産力を示したものであるが，森林 は，一般に他の生態系に比べて生産力が高い。しかも， 日本の森林は，その中でもきわだって高い生産力を示 し，たとえば，東日本の落葉広葉樹林の一次生産力は 15 
表 1 地球の陸地上の各生陆系の一次生産力 ${ }^{(2)}$

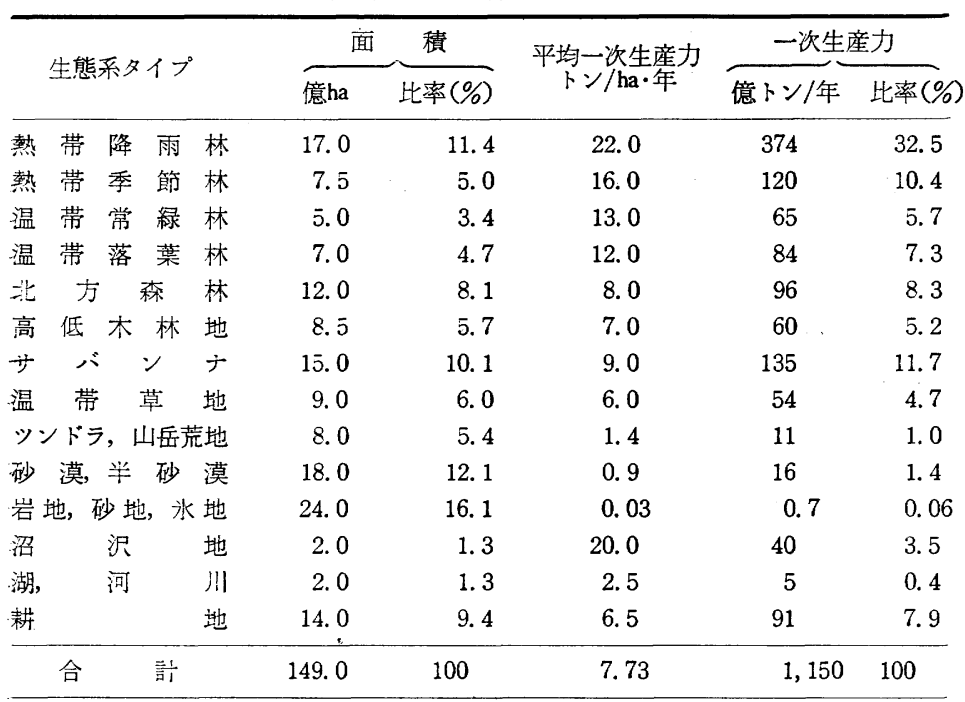

つきをとうこうした事情から，わ が国古代の水田は，現在の稲作中心 地の広がる大きな河川の沖積平野で はなく，小河川の両側に連なる自然 堤防の背後の小低湿地に始まってい る. そして，古代の豪族や大和朝廷 の第一の仕事は, 小さくても豪雨の ときには一転して暴れ川になりか权 ない小河川の治水と，水路を引き， 溜池を掘って用水を確保することで あった，沖積平野を抱觉る大河川の 治水は，とても手に負觉るものでな く,この仕事は，はるか後世の戦国 時代の大名たちと徳川幕府の手に残 された。

トン/ha・年前後で, 表 1 の温帯落葉林の 12 トンより高 紀元前 4 世紀ごろ北九州に出現した稲作が，弥生時代 の 600 年あまりの間に, 日本列島を綎断して本州の北端 にまで達したことは，さきに述べたと拈りだが，これに は当然, 耕地としての水田造成が伴ったはずである. 水 田遗構の発掘事例はまだ少ないけれども, 当時の稲作は 主として石器と木製農具で行なわれたらしい。しかし， 水路やあぜに整然と打ち込まれた杭，矢板などは鉄器文 明の裏打ちなしには考号られないのである.つづいて, 古墳時代をへて日本が国家の体裁を整えだすと，水田造 成は爆発的に進み，8世紀には現在のわが国の水田面積 の約 3 分の $1 ， 100$ 万へクタールを越える水田がすでに あったことが記録かららかがわれる(3). 当時の水稲の推 定収量はへクタールあたり 1 トン，現在の収量に比べれ ばもちろん比較にならないが，それでも最近のラオス， カンボジアなどの 平均水稲収量に 比肩しうる高さであ る.

\section{2. 日本の耕地にはどんな特色があるか}

現在, わが国の地目別の 耕地面積は水田 298.9 万人 クタール, 烟 124.9 万ヘクタール, 草地その他 117.3 万ヘクタール，全国土面積に対する耕地率は $14.4 \%$ で ある、しかし，わが国の農業は，これらの数字から読み とられる以上に水田稲作に压倒的な比重をかけて発展し

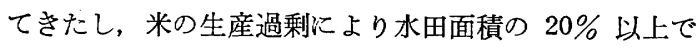
転作が行なわれているいまなお，その基本的性格は変わ っていない。 
日本農業が稲作中心で発展してきたのには，いくつか の理由がある、第一に，日本列島がアジア・モンスーン 地带に属していて, 中緯度であるにもかかわらず, 熱帯 なみの高温な夏をもち, かつ夏雨型の豊富な降水があっ て, 稲作に適していること, 第二に, 水稲は高く安定し た生産力をるった作物である上に，湛水条件ではいくら 連作を続けても，けっして連作障害を起こさない特性を もっていること、第三に、山が多く傾斜地に富んだわが 国の地形の特徵から, 重力を利用した水田用水の確保, 分配, くり返し利用が此較的容易で, 水田の水管理がら くにできること，第四に，水田の条件では，モンスーン 気候下の土壌の 宿命である酸性化, 地力消耗が 抑制さ れ，また，湛水という条件は畑状態の耕地に比べて雑草 の発生を約 6 分の 1 に抑党，士壤浸食の危険も小さいこ と、などが主要な理由である(4).

それに対して, 畑状態の耕地では, 豊富な降雨がたえ ず土壤を洗脱するため, 土壤の酸性化と地力消耗が激し く進行するし，傾斜地では浸食の危険も高い，そして， 何よりも，わが国の高い自然生産力を背景にして猛烈な 勢いで繁茂してくる雑草との血みどろの闘いが待ちらけ ている．作物の側からいえば，わが国の気候条件に適し た畑作物はたくされあるのだが，水田稲作に比べると， 耕地管理・作物管理の上で格段の苦労を余儀なくされる のである.

こうした状況のもとで，わが国の農業が稲作中心に傾 舖するのは当然である. 事実, 山岳高冷地や北海道東部 のように気候上稲作の困難な地帯を別にすれば，畑は，

用水が得られないとか，傾斜が急とかの条件の悪い土地 に仕方なく造成されてきたのが害態 である、まして，畜産のためのまと まった草地など，伝統的なわが国の 農業の中に存在する余地はほとんど なかった、そこで，農業のかなめで ある稲作を行なら場としての水田で あるが，水田は造成にたいんんな労 力がかかる反面，水稲はいくらでも 連作がきくから，いったん造成され ると半永久的に固定される。この事 情はアジアの稲作諸国でも同じであ るけれども，水を大河の氾濫に依存 する大陸アジアのデルタ平野の水田
と違って，わが国では沖積平野といえども多少の傾斜を もつ関係上，水源さえ確保すれば，望むときに水田に水 を入れ，また排除する水管理がしやすい，つまり，日本 の水田は水が制限因子にならないので，必然的に稲作は 集約化の方向をとる. 集約化の基本は土つくくであるか ら，古来わが国の農民は，あらゆる手だてを講じて水田 土壌の肥沃化をはかってきた。堆きゅう肥はもとより， 入会地の野草, 森林の下草や下枝, そして畑の生産物残 椬まで水田に投入した。そのため，ただでさえ地力維持 の容易な水田はますます肥沃になり，畑は反対にますま すやせることになった、このことは、日本農業に和ける 水田と畑の相対的地位の差をさらに開かせ, 他のアジア の稻作諸国にもみられないほど，固定的で動かない水田 と畑への耕地の二分割を実現したのである。肥沃な水田 とやせた畑への耕地の固定的二分割，これが日本の耕地 の世界に類例をみない特色といえよう。

次に，水田と畑それぞれについて，わが国の耕地の特 徵をみることにしたい。

\section{水田}

まず水田であるが，前述の事情から，日本の水田は徹 底した人工耕地，つくられた土蚈の性格が深い。わが国 のように，綿密な土缞管理，水管理のもとで稻作を繰り 返した場合，水田の土壤は，鉄やマンガンが表層から次 第に下層に移り，かつ全体の色が青味がかってくるグラ イ化作用を受けて，特別の性質をもつょらになる。これ を水田土壤化作用という。しかし，この作用は，水田で あればいつでも起こるわけでなく，たとえば傾斜がほと

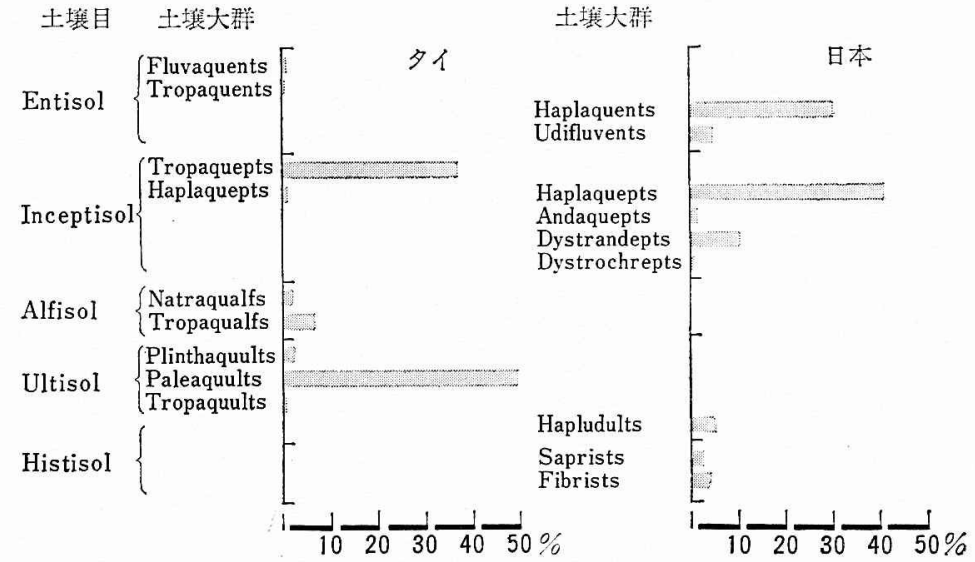

図 2 日本とタイの水田土壤の分布スペクトル (Vacharotayanら ${ }^{(6)}$ にり作図) 


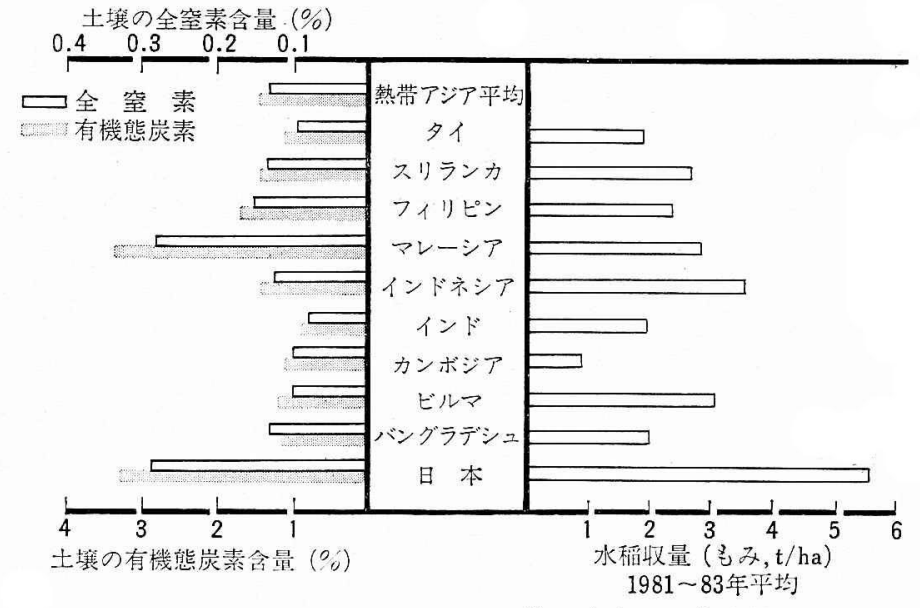

図 3 日本および熱帯アジアの水田土袞の窒素・炭素含量と水稲収量

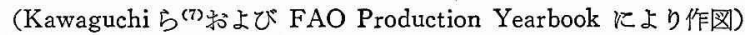

良性の原因は自然肥沃度，養分の不 足々か，土層の深さ，急傾斜，浸食 とかが高位を占め，水田とはまった く対照的である. 水田に比べて，い が畑が自然立地条件の悪いところ に追いやられ，地力管理すな陉ざり にされてきたか，この図からもらか がえるであるう。

一方，方が国に比較して，はるか に乾燥した気候の欧米諸国では，農 業は最初から畑作中心であり，とく に穀物畑は，各国とも最も条件のよ い, 肥沃な土壌地帯に 展開してき た. たとえば, アメリカの小麦べル
えどなくて，水の下方浸透がみられないタイの中央平原 では起こらないのである(5). 図2は，日本とタイの水田

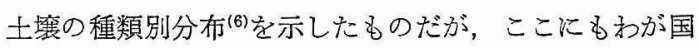
の水田土猿の人工的性格があらわれている. 日本の水田 土堙で高い比重を占める Haplaquents と Haplaquepts は，それぞれグライ土，灰色低地土に対応するが，両者 とも上述の水田土壤化作用で生成した土壤とみてよい。 それに対して，タイの水田で主要な Tropaquepts（酸性 硫酸塩土）と Paleaquults（赤黄色ポトゾル性土）は， 熱帯に広く分布する自然土堙である.

長い歴史のなかで，人間の努力により培われた日本の 水田土培の肥沃さは, 地力の重要な要素の一つ, 土壤有 機物含量の高さにも示される. 図 3 は熱带アジア各国と 日本の水田土壌の有機態炭素々全窒素の含量を比較した もので, 日本は熱帯アジア平均の 2 倍以上ある(7). 土壌 中の有機物含量と水稲収量とは, 必ずしも直接結びつく ものではないが，図3に同時に揭げた収量を見れば，両 者の間にはやはり平行関係が認められる.わが国の水田 土壤の生産力は高いといってよい.

\section{畑}

次に, 烟はどうであろうか，図 4 注，農林水産省が都 道府県農業試験場の協力を得て実施している土壌環境基 礎調査の結果に基づいて，吉池(8)がまとめた不良土堙の 面積割合である。一見してわかるように，何らかの改良 を必要とする不良土壤が水田では全面積の $39.3 \%$ であ るのに対し，畑では $69.2 \%$ と著しく高い。乙か子，不
トは，いわゆる大平原のチェルノーゼム，プレイリー土 といった土壤地帯に連なっている。チェルノーゼムすな わら黒土は，土培の王様といわれるほど肥沃な土壤であ り,プレイリー土む，自然状態で全窒素含量が $0.37 \%$, 全炭素含量が $2 \%$ 以上で, 森林土壤より約 $50 \%$ 有機物 を多く含み, わが国の水田土袞の水準に匹敵する.

日本とアメリカの畑の肥沃度の差は歷然としている が，図5に示したように小麦の収量には大差がない，そ れは，アメリカの小麦生産が，土堙の肥沃さにもかかわ らず，きびしい乾燥，水分不足の条件下で行なわれてい るからである. 1979 年度のアメリカ農務省の年次報告, つまり農業白書は，国際児童年を記念して子供向けの絵 本スタイルをとった面白いものであるが，そこから小麦 生産についての説明を抜すいしてみる。「きみはカンザ スに住んでいるかい？それなら，きみは大平原を越光 て何マイルも何マイルも広がっている小麦畑を見たこと

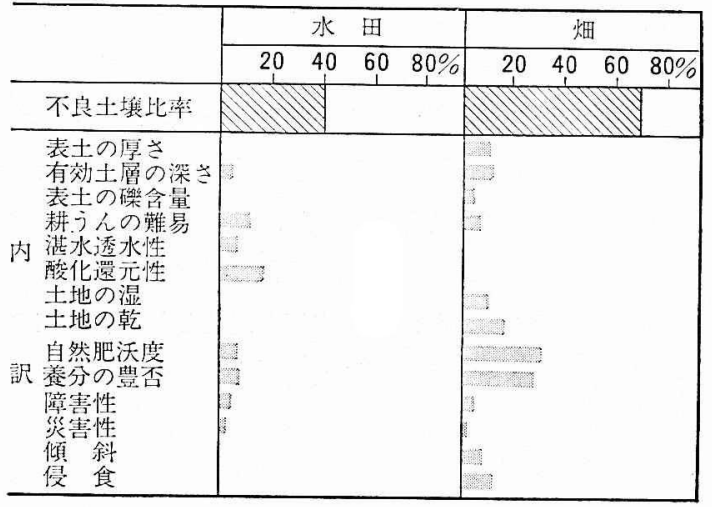

図 4 わが国の不良土壤の面積比率とその原因 ${ }^{(8)}$ 


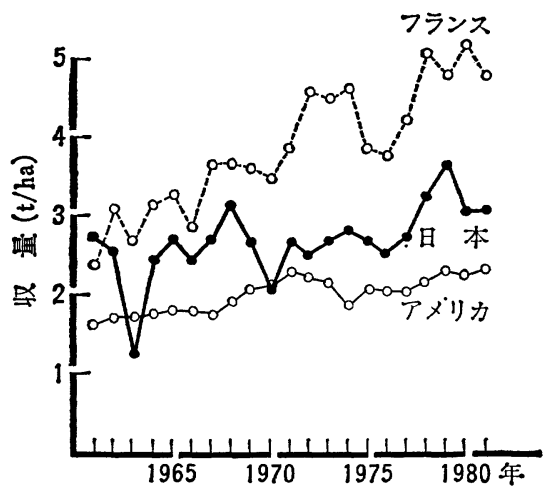

図 5 日本, アメリカおよびフランスの小麦収量の比較 (FAO Production Yearbook により作図)

があるね. カンザス州は，ほかのどの州よりもたくさん の小麦を作っているからさ．……西カンザスの小麦作り 農家は，自分の土地を二つに分ける。一つの烟にはその 年小麦を植え，もら一つの烟は来年用だ．西カンザスは すごく乾いていて，雨が少ないから，一つの小麦畑を収 穫する—ふつら 7 月の初めだが—と，その畑は打休 みに入る. 1 年近く休閑して，雨や雪からの水分を吸わ せ，貯えるのだ．次の年の 4 月，畑は仕事に 戻ってく る.ささあ何が始まるか. 」(9). そして，4月の畑の耕起か ら 9 月の播種, 翌年の 7 月の収穫までの毎月の農作業の 説明が続く，興味深いのは，冬越しした小麦が再び伸び 始める翌年 3 月に「ときには牝牛を小麦畑に連れてきて 放牧する，放牧は，小麦がたくさんの穂を出し，たくさ んの実を稔らせるのに，役立つことが多いのだ.」とし ていることである．ローマ時代の二圃式農法を思わせる 1 年小麦作 1 年休閑の輪作, 生育中の小麦畑での乳牛放 牧など，わが国では考兄られないことだが，これが乾燥 地帯のアメעカの小麦作なのである.

ここで私が述べたいのは，アメリカの小麦作の紹介で はなくて, 耕地がその生産力を発揮する上で, 克服すべ き制限因子は同一でない，ということである。アメリカ の小麦ベルトでは，土壤の肥沃性は問題でなく，最大の 難関は水分である．それに対して，わが国の畑では，水 分は問題にならず，土地・土堙条件の劣悪さが生産力の 発揮を抑えている. しかる，水田と対比した場合，烟の 劣悪性は, 自然条件よりも歴史的, 人為的な様相が濃い のである.

\section{3. 日本の耕地の生産力}

わが国の農業が伝統的に稲作中心であり, 耕地につい ても水田に集中して肥沃性の向上をはかってきたのは, さきに述べたと扣りである。こうした事情を反映して， わが国の水稲収量は高い. 因3に示したように, 最近の 日本の水稲収量はへクタールあたり玄米で 4.8 トン, む み換算で 6 トン水準であり, 熱帯アジア諸国の $3 \sim 2$ 倍 の高さにある.また，収量からわらや根株まで含めた缜 物生産量, すなわち表 1 に揭げた一次生産量を推定して みると, 熱帯アジア諸国では 6〜 7トンで, 世界の耕地 の平均なみであるのに対し，日本は約 12 トンで平均の 2 倍に迫る。

畑ではどうであろらか，小麦を例にとると，最近の日 本の収量はへクタールあたり約 3 トン, アメリカは 2.3 トンである. 同様に一次生産量は日本が約 9 トン, アメ リカが約 7 トンになる．ところで，日本では毎年小麦を 作り，アメリカでは休閑を置いて 1 年おきだから，小麦 畑全体になおすと, アメリカの小麦畑の一次生産量は 3.5 トンに低下して，世界の耕地平均の半分ちょっとと いう低さになる．両者の数字比べからは，条件の劣悪さ にもかかわらず，日本の畑はなかなか健闘しているよう 思える。しかし，西ドイッ, フランス，イギリスなどの ヨーロッパ諸国の小麦収量は 4.5〜5 トン水準で, 輪作 はしても休閑は置かないから，一次生産量は 13〜15 卜 ンと，世界平均の 2 倍以上になる。 また，アメリカでも 小麦ベルトより雨量に恵まれたコーン・ベルトで生産さ れるトウモロコシの収量は 6 ～7トンといら驚くべき高 さで，やはり休閑は行なわれないので，一次生産量は 12〜14 トンである. 総じて，わが国の畑作は，劣悪な条 件下での健闘は称えられるものの，先進諸国の中では収 量水準，一次生産量とも，低位にあるといわざるをえな い.

個々の作物については上述のとおりであるが，アメリ カの 小麦で少し触れたように, 耕地には必ず 1 年に 1 作物が植えられるとは限らないから，耕地の生産力とい う場合，作付体系を考慮しないわけにはいかない，わが 国の水田を例にとれば，1950 年ごろまでは，水稲の収 嚄後の期間を利用して，水田面積の $20 \sim 30 \%$ で小麦・ 大麦・ナタネなどの裏作が行なわれていた，それで，裏 作物を加算した水田の一次生産力は，1900 年にはへク 


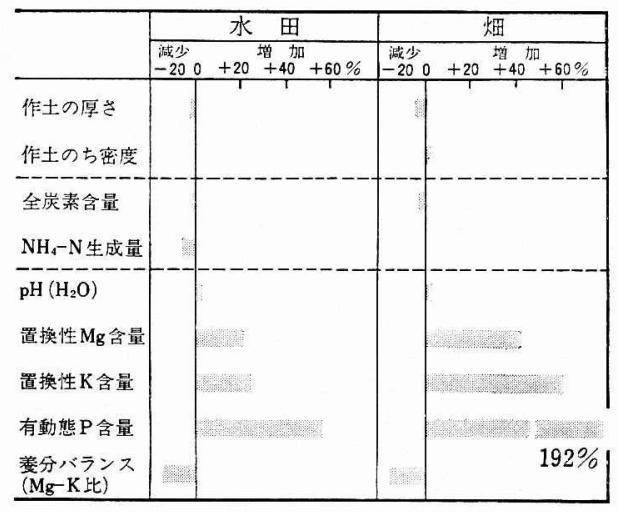

図 6 最近における土壤の地力指標の変化 ${ }^{(8)}$

タールあたり 7 トン弱（水稲単独では 5.6 トン）, 1925 年には 8.5 トン (同 7.1 トン), 1950 年には 10 トン (同 8.1 トン) と増加を続けてきた. ところが，このこ ろ外国からの款物輸入圧力が高まるとともに，小麦・大 麦をはじめとする畑作穀物の栽培は衰退し，水田裏作も みるみる崩壊してしまった。ささらに 1970 年代以降は, 米の生産過剩による稲作調整，水田の畑作転換が始ま り，現在もなお続いている，そのため，1950 年代以降， 水田の一次生産量はほぼ 10 トンの水準で全然伸びてい ない. 1950 年を基準にして，米の収量は約 $45 \%$ も増加 しているから, 裏作の崩壤や稲作調整・畑作転換がいか に耕地としての水田の生産力発現の足をひっぱっている かがわかるであらう。

これらのことと重なって, 1960 年代に入ると, 日本の 農業は一方では技術革新，もら一方では高度成長を背景 にした歯止めのない農業衰退の受難の時代を迎える．新 しい品種と施肥法, 新農薬による防除, トラクター・コ ンバインに象徴される機械化などが嵐のように進行する なかで，農産物輸入の圧力はますます強まり，商工業と の収入格差から農村の人口流出，農民の兼業化がとめど めもなく進む. このような状況のもとで，大きな問題と して浮かび上がってきたのが，いわゆる耕地の地力問題 である。

いったい，わが国の耕地の地力は本当に落ちてきてい るのか，それともそんなに心配することはないのか．図

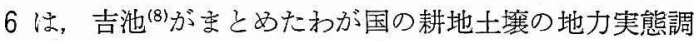
査の結果で, 1975 77 年の調査による土堙の 関連指標 を前回 1959〜61 年の 調査と比較する 方法をとってい る. 図6に示された結果から, 水田土壤と畑土塆に共通 して，耕深が浅くなり作土が硬くなってきていること，
土壤中の有機物含量は低下ぎみであること，土壤の酸性 は矯正され，養分も豊富になったが，その一方で養分 間のバランスが崩れつつあること，などの傾向が読みと れる.もちろん，これは平均值としての話であって，て らでない土壌も多いのであるが，全体的な傾向から，わ が国の耕地にはやはり地力問題が存在するといわざるを えない、そして、耕深が浅くなったのは歩行型トラクタ 一によるロータリー耕，作土が硬くなったのは乗用型に ラクターによるロータリー耕ないし耕らんの省略, 土塞 有機物の低下は堆きゅら肥などの有機物の施用の減少， 養分の富化と養分間のバランスの崩れは主として化学肥 料の多施と関連がある, と推察されていて，いずれも機 械化・化学化を軸にした農業技術革新の影の部分が表面 化したものといってよからう．自然の土地を耕地化し て，肥沃な耕地土壊をつくり上げるのに，長い年月を要 するのと同様，土壤に気がかりな徵候が現れたからとい って，耕地はただらにとの生産力を失うわけではない， しかし、それたからなおさらのこと，対策は早いにこし たことはないのである。

\section{4. 日本の耕地の進むべき道}

私は, 水田と畑への耕地の固定的な二分割, さらに肥 沃な水田とやせた畑といら耕地生産力の二重棈造が, え が国の耕地の特色であると述べた， その両者に，現在， 地力問題として考えなければならない共通の銜候が現わ れているのは, やはり重大である. もら一点, 1950 年 ごろから 水田と称する 耕地の 年間一次生産量が, 水稻 収量の増加にもかかわらず，横ばいを続けている 事実 をるら一度ここで指摘して絡きたい，原因は明らかで ある. 1960 年代むでは裏作の崩壊, 1970 年代以降は稲 作制限による畑転換と転換畑作物の収量の低さ，が原因 である、これは，太陽エネルギーの固定装置である耕地 の基本的性格からしても，好ましいことではない。とく に，水田から畑転換した「水田」耕地が，伝統的な日本 農業における畑なみの管理しか受けられないとしたら， 営々として筑き上げた肥沃性を一方的に失って，やせた 畑を増加させることになりかねないのである。

私は，国民のかけが党のない共有財産であるわが国の 耕地に，高い生産力を発揮しらる能力を絶えず与えて和 くべきだと思う，その意味で，日本の畑を輸入農産物の 強圧で荒廃するまま放置したり，また米の需給調整のた 
めに機械的に水田の一部を稲作から引き離し，蓄積した 肥沃性をで失わせることには疑問を感ずる，とれと同時 に，農業生産の側む，耕地の水田と畑への二分割を固定 化して考兄，もっぱら水田にのみ肥沃化の努力を注ぎこ んできた日本農業の伝統的観念を，ここらで根本的に見 直してみる必要がありはしないか，そのためには，わが 国の耕地を稲作にも烟作にも使えるように沉用化して， 何年か毎に稲作と畑作を交代させる田畑輪換を行ならこ とである．よく管理された田畑輪換のもとでは，「水田」 に蓄積された肥沃さは失われず，「畑」には新たな肥沃 さを付与することが可能であろう．米の生産過剩のもと で，わが国の食糧自給率を引き上げるためには，稲作の 調整とともに思いきった畑作振興は避けられない，私 は，水田・烟を合わせて耕地の沉用化と，沉用化された 耕地での畑作振興を提唱したい。同時に，それは，わが
国の耕地の生産力を高く維持する道なのである。

\section{文. 献}

1）小山修三：“䋥文時代”，中公新書，1984.

2) R. H. Whittaker : "Communities and Ecosystems", 2nd ed., MacMillan, N.Y., 1975 ; 宝月欣二訳 : “生態学概 説”，培風館，1979.

3）盛永俊太郎：“日本の稲”，養賢堂，1957.

4）吉田武彦：“水田軽視は日本農業を亡ぼす”，農文協，1978.

5）三土正則：“稲作による土㖶の変化”, 科学, 48, 602(1978).

6) Sorasith Vacharotayan \& Y. Takai (ed.): "Paddy Nitrogen Economy", Tokyo University of Agriculture, 1983.

7) K. Kawaguchi \& K. Kyuma : "Paddy Soils in Tropical Asia", The University Press of Hawaii, 1977.

8）吉池昭夫：“わが国耕地の地力の実態と变化”，農業および 園芸, 57, 110 (1982).

9) USDA : "What's to Eat?", US Department of Agriculture Yearbook, 1979.

お知らせ

\section{生物化学工学 若手研究者の集い}

日 時: 昭和 60 年 8 月 1 日 (木) 8 月 3 日 (土)

場 所：北海道自治会館

于 060 札幌市中央区北 4 条西 6 丁目 2 番地

8 011-241-9111

（札熀駅より徒歩 5 分・道庁舎北隣り）

本集いは, 生物化学工学, 応用微生物学, 分子生物学などの 研究徒従事する若い研究者 (大学の助手や院生, 企業の研究員 など）を中心とする勉強会です.この催しの目的は若手研究者 間の交流を通じて，自己の尃門分野以外のさまざまな研究に触 れることで研究の視野をより広げることにあります。集いは日 本農芸化学会大会（於北大）の直後に行なわれますので，特に 農化大会参加者の御応募を歓迎いたします。

$$
\text { 日程ならびにプログラム（予定） }
$$

第1日：8月1日（木）

夕食後, 自己稆介ならび烈親会

第2日：8月2日（金）

動植物細胞の組織培養 : (1)動物細胞による物質生産のため の遗云子操作・小野寺一清(東大農)/(2)培養細胞飞拈仔
るソマクローナル変異・佐藤文彦(京大農)／(3植物細胞

の大量培養・原 康弘(三井石油化学工業)

真核細胞の遺云子構造：(1)Saccharomyces cerevisiae の 細胞核構造・土屋英子(広大工)/(2)光合成遺卮子の構造 之発現・山田 隆(三菱化成生命研)

放線菌の遺伝子操作 : (1)ストレプトマイシン生産菌におけ る宿主べター系の開発之利用・大貫哲男(阪大工)／(2) ビアラホス生合成遺伝子のクローニングとクラスター樍 造の解析・村上 健(明治製菓中研)

第 3 日：8月 3 日 (土)

寒冷地の微生物：(1)大腸菌の 低温耐性変異 - 川本伸一 (北大農) /(2)廃水処理への微生物機能の応用之問題点 · 清水達雄(北大工)

下記の要領で御応募下さい.

参加費 : 学生 $¥ 15,000$ （2泊 3 日 5 食付）

一般 $¥ 20,000$ (2 泊3 日 5 食付)

人数:約 50 名

締 切: 6 月 30 日 (消印有効)

宛 先: $\overline{\mathbf{T}} 565$ 吹田市山田丘 2-1 大阪大学工学部醱酵工学科 松村正純 용 06 (877) 5111 内線 4376
化学と生物 Vol. 23, No.5 (258 号)

昭和 60 年 5 月 25 日発行

\section{（月 刊）定価 680 円}

編集者：社団法人 日本農芸化学会

発行者：株式会社 学会出版センター 113 東京都文京区本揤 6-2-10 (東大正門前)

印刷者：新日本印刷株式会社 挿図・伊藤 允三，装幀・万膳 寛

\section{企画委員粟飯原景昭, 旭}

今田哲, 鵜高 重三, 江藤 小川 智也, 小此木成夫, 菅野

\section{桑本 融, 斎尾 恭子, 志賀} 高橋 秀夫, 千葉

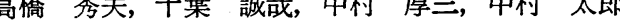
名取 俊二, 並木 満夫, 原田宏, 平田 熙, 古屋 晃, 堀口 雅昭, 松本 義明, 村上 浩二, 山口 勝己

企画理事 小林 彰夫, 丸茂 晋吾 ○企画委員長 